\title{
Karbon Tetraklorürün Neden Olduğu Akciğer Hasarında L-Karnitinin Antiapoptotik ve Histopatolojik Değişiklikler Üzerindeki Rolü
}

\section{The Role of L-Carnitine in Antiapoptotic and Histopathological Changes in Lung Injury İnduced by Carbon Tetrachloride}

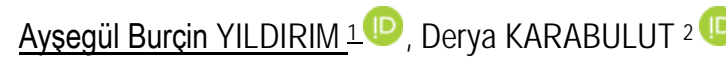

1 Gaziantep İslam, Bilim ve Teknoloji Üniversitesi, Tıp Fakültesi, Histoloj-Embriyoloji Anabilim Dalı, Gaziantep

2 Erciyes Üniversitesi, Tıp Fakültesi, Histoloji-Embriyoloji Anabilim Dalı, Kayseri

Öz.

Amaç: Karbon Tetraklorür (CCI4) maruziyetinin akciğer üzerindeki toksik etkileri, bu toksik etkilere karşı L-karnitin'in koruyucu ve iyileştirici rolü ve kaspaz-3 aktivesinin değişiminin araştıııması amaçlanmıştır.

Materyal ve Metod: Çalışmada 25 adet sıçan her grupta 5 adet olacak şekilde 5 gruba ayrıldı. Deneyde yer alan gruplar şu şekilde oluş̧uruldu. Grup I: Kontrol grubu, 6 hafta boyunca haftada iki kez $0.2 \mathrm{ml}$ zeytinyağı intraperitonal (ip), Grup II: L-karnitin grubu, 6 hafta boyunca haftada iki kez $200 \mathrm{mg} / \mathrm{kg} \mathrm{L-karnitin} \mathrm{(ip),} \mathrm{Grup} \mathrm{III:} \mathrm{CCl4} \mathrm{grubu:} 6$ hafta boyunca haftada iki kez $0.2 \mathrm{ml}$ $1100 \mathrm{~g} \mathrm{CCl} 4$ (ip), Grup IV: CCl4 + L-karnitin grubu, 6 hafta boyunca haftada iki kez CCl4 $0.2 \mathrm{ml} / 100 \mathrm{~g}$ uygulamasından yarım saat sonra $200 \mathrm{mg} / \mathrm{kg}$ L-karnitin (ip), Grup V: L-karnitin + CCl4 grubu, 6 hafta boyunca haftada iki kez her $0.2 \mathrm{ml} / 100 \mathrm{~g} \mathrm{CCl}$ uygulamasından 24 saat önce $200 \mathrm{mg} / \mathrm{kg}$ L-karnitin (ip) verildi. Hem CCl4 hem de L-karnitin uygulamasına 6 hafta boyunca haftada iki kez devam edildi. Akciğer histopataolojisi değerlendirildi ve kaspaz-3enzim aktivitesi immunohistokimyasal yöntemle belirlendi. Kaspaz-3 immunpozitif hücre sayımı yapııdı.

Bulgular: $\mathrm{CCl} 4$ uygulanan grubunun akciğer dokusu histolojisinde belirgin fark gözlenmiștir. Alveolar intersitisiyel alanlarda artış, bronşiol epitelinde vakuolizasyon ve dejenerasyon gibi histopatolojik değişikliklere rastlanılmıştır. İstatistiksel analiz sonuçlarına göre Grup III ve V, kontrol grubuna göre anlamlı olarak yüksek bulunmuştur. L-karnitin CCI4 den önce verildiğinde kaspaz-3 hücre sayısı kontrol grubundan yüksekken, L-karnitin sonra verildiğinde kaspaz-3 hücre sayısının kontrol grubuna benzer şekilde olduğu görülmüştür

Sonuç: Sonuç olarak, alveolar hasar oluşumunda L-karnitin takviyesinin antiapoptotik etkisinin olduğu ve tedavi edici olarak kullanılmasının daha büyük önem taşıyacağııı düşünmekteyiz.

Anahtar Kelimeler: Karbon Tetraklorür, Kaspaz-3, L-karnitin, Apoptoz.

Abstract

Background: The aim of this study to investigate the toxic effects of Carbon tetrachloride (CC/4) exposure on the lung, the protective and therapeutic role of $\mathrm{L}$-carnitine against these toxic effects and the change of caspase-3 activity.

Materials and Methods: In the study, 25 rats were divided into 5 groups, with 5 in each group. Groups were created as follows. Group I: Control Group: $0.2 \mathrm{ml}$ of olive oil twice a week for 6 weeks Intraperitoneal (ip); Group II: L-carnitine group, $200 \mathrm{mg} / \mathrm{kg}$ L-carnitine twice a week for 6 weeks (ip); Group III: CCl4 group: 0.2 ml/100 g CC14 twice a week for 6 weeks (ip); Group IV: $\mathrm{CCl} 4+\mathrm{L}$-carnitine group, $200 \mathrm{mg} / \mathrm{kg} \mathrm{L}$-carnitine half an hour after applying $0.2 \mathrm{ml} / 100 \mathrm{~g} \mathrm{CCl} 4$ twice a week for 6 weeks (ip); Group V: L-carnitine + CCl4 group, $200 \mathrm{mg} / \mathrm{kg}$ L-carnitine 24 hours before $0.2 \mathrm{~m} / 100 \mathrm{~g} \mathrm{CCl} 4$ application twice a week for 6 weeks (ip). Both $\mathrm{CCl} 4$ and L-carnitine administration was continued twice a week for 6 weeks. Lung histopathology was evaluated, and caspase- 3 enzyme activity was determined by immunohistochemical method. Caspase-3 immunopositive cells were counted and statistical analysis was performed.

Results: An obvious difference was observed in the lung tissue histology of the $\mathrm{CCl} 4$ administered group. Histopathological changes such as increase in alveolar interstitial areas, vacuolization and degeneration in bronchiolar epithelium were encountered. According to the results of statistical analysis, Group III and Group V values were significantly higher than the control group. When $\mathrm{L}$-carnitine was given before $\mathrm{CCl}$, the number of caspase- 3 cells was higher than the control group. And when L-carnitine was given later than $\mathrm{CCl}$, the number of caspase-3 cells was similar with the control group.

Conclusion: As a result, we think that L-carnitine supplement has an anti-apoptotic effect and it can use as a therapeutic agent in alveolar damage formation.

Key words: Carbon tetrachloride, Caspase-3, L-carnitine, Apoptosis

\section{Sorumlu Yazar I \\ Corresponding Author}

Dr. Öğr. Üyesi Ayşegül Burçin
YILDIRIM

Gaziantep İslam, Bilim ve Teknoloji Üniversitesi, Tıp Fakültesi,

Histoloji-Embriyoloji Anabilim Dalı, Gaziantep.

E mail: aysegulburcin@gmail.com Tel: 05449209384

Geliş tarihi / Received:

09.04.2020

Kabul tarihi / Accepted: 22.05.2020

DOI: 10.35440/hutfd.717101 


\section{Giriş}

Hayvan modellerinde toksisiteyi indüklemek için kullanılan ksenobiyotiklerden biri de karbon tetraklorür $(\mathrm{CCl} 4)$ dür. Pulmoner toksik (1), nefrotoksik (2), hepatotoksik (3) etkiler gösterir ve bu organlar dışında diğer organlarda da hasarlara neden olur. Bu kimyasala maruz kalmanın oksidatif stresi indüklediği ve serbest radikallerin oluşumu ile doku hasarına neden olduğu bilinmektedir (4).

$\mathrm{CCl} 4$, solunum, mide-bağırsak sistemi ve cilt tarafından absorbe edildikten sonra, sitokrom P-450 tarafından metabolize edilir ve toksik etkilerini metabolitleri olan triklorometil ve triklorometil peroksil serbest radikalleri ile gösterir (57). Akciğer hücresi zarının yağ asitleri ile etkileşen bu serbest radikaller lipit peroksidasyonunu ve DNA parçalanmasını arttıır ve akciğer hasarı oluşturur (8, 9). CCI4'ün, interstisyel hücre dejenerasyonları, jnflamatuar hücre artışı, kan damarlarında genişleme ve fibrozis ile akciğer toksisitesine neden olduğu gösterilmiştir $(5,10,11)$.

Ksenobiyotik maddelerin oluşturduğu hasarlar nedeniyle hücrelerde apoptoz ve nekroz oluşabilir $(12,13)$. Apoptoz veya programlanmış hücre ölümü, hücre proliferasyonu ve hücre ölümü arasındaki hassas dengeyi koruyarak hücresel homeostazda önemli bir rol oynar. Apoptoz için gerekli hücre içi olaylardan biri, Sitokrom C'nin sitosol içine salınması ve kaspazların aktivasyonudur $(14,15)$. CCl4, kaspaz yolunu aktive ederek apoptozu artırır, böylece doku hasarına yol açar (16). Apoptozun önemli belirteci olan kaspaz-3 gibi proteinlerin dokulardaki sentez oranları oldukça önemlidir.

L-karnitin, memeli metabolizmasının enerji üretiminde, organik asitlerin detoksifikasyonunda ve uzun zincirli yağ asitlerinin mitokondriyal membran naklinde işlev gören temel bir taşıyıcıdır. L-karnitin'in doku hasarını önleyen ve antioksidan enzim aktivitelerini arttıran detoksifiye edici bir etkiye sahip olduğu bilinmektedir (17). L-karnitin reaktif oksijen türlerinin oluşumunu önler, serbest radikalleri temizler, hücreleri peroksidatif strese karşı korur $(18,19)$. Aynı zamanda apoptozda rol alan proteinleri düzenleyerek antiapototik etki gösterir (20).

İmmunohistokimyasal ve ışık mikroskobik düzeyde yapılan bu çalışmada, CCl4 maruziyetinin akciğer üzerindeki toksik etkileri, bu toksik etkilere karşı L-karnitin'in koruyucu ve hasarı iyileştirici rolü ve kaspaz-3 aktivesinin değişiminin araştıııması amaçlanmıştır.

\section{Materyal ve Metod \\ Hayvanlar}

Bu çalışmada Erciyes Üniversitesi Deneysel ve Klinik Araştırmalar Merkezi'nden (DEKAM) elde edilen 200-300 g ağırlığında, 2-3 ay / 8-12 hafta yetişkin 25 adet erkek Sprague dawley sıçan kullanıldı. Bu projede kullanılan dokular için Erciyes Üniversitesi Hayvan Deneyleri Yerel Etik Kurulu tarafından (14.02.2018 tarihli onay, 18/034 sayilı karar) etik kurul onay belgesi alındı. Kafesler içinde tutulan sıçanlara günün normal düzeninde $21^{\circ} \mathrm{C}$ ve 12 saatlik aydınlık/karanlık ortamında su ve besin intiyaçları sağlandı. Denekler tartılıp, ağırlıkları birbirine yakın olanlar bir araya getirilerek deney grupları oluşturuldu.

\section{Kimyasallar}

Akciğer hasarının indükleyicisi olarak karbontetraklorür (Sigma-Aldrich, St. Gallen, İsviçre) zeytinyağında çözdürülerek kullanıımışır. Antioksidan olarak L-karnitin (SigmaTau, Pomezia, İtalya) kullanımışıı.

\section{Deney Protokolü}

Deney grupları aşağıda ayrıntılı şekilde açıklanmıştır.

Grup I: Kontrol grubu (n:5), 6 hafta boyunca haftada iki kez intraperitonal (ip) $0.2 \mathrm{ml}$ zeytinyağı verildi.

Grup II: L-karnitin grubu (n:5), 6 hafta boyunca haftada iki kez (ip) 200 mg / kg L-karnitin uygulandı.

Grup III: CCl4 grubu (n:5), 6 hafta boyunca haftada iki kez $0.2 \mathrm{ml} / 100 \mathrm{~g} \mathrm{CC} 14$ zeytinyağında çözdürülerek (ip) uygulandı.

Grup IV: CCl4 + L-karnitin grubu (n:5), 6 hafta boyunca haftada iki kez (ip) CCl4 $0.2 \mathrm{ml} / 100 \mathrm{~g}$ uygulamasından yarım saat sonra $200 \mathrm{mg} / \mathrm{kg}$ L-karnitin (ip) verildi.

Grup V: L-karnitin + CCl4 grubu (n:5), 6 hafta boyunca haftada iki kez (ip) CCl4 $0.2 \mathrm{ml} / 100 \mathrm{~g}$ uygulamasından 24 saat önce $200 \mathrm{mg} / \mathrm{kg}$ L-karnitin (ip) verildi. (Şekil 1).

Hem CCl4 hem de L-karnitin uygulamasına 6 hafta boyunca haftada iki kez devam edildi. Deneyin sonunda, sıçanların akciğer dokuları ketamin $(75 \mathrm{mg} / \mathrm{kg})+$ ksilazin (10 mg / kg) anestezi altında çıkarıldı.

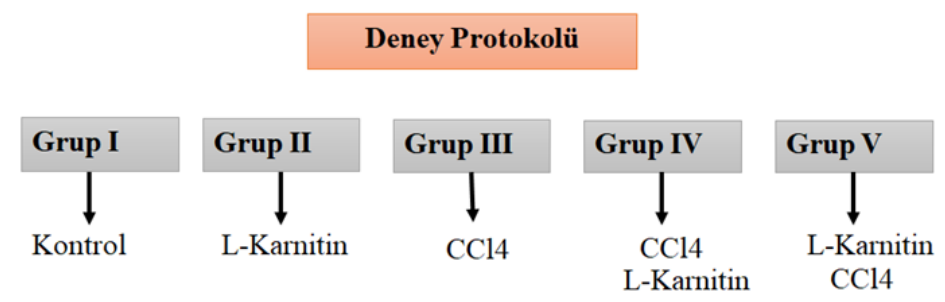

Şekil 1. Deney Protokolü Şeması

\section{Histolojik Analiz}

Deney sonunda \%10 luk formaldehid solüsyonuna alınan akciğer dokuları tespit edildi. Tespit sonrası artan dereceli alkol serilerinden geçirilen (\%50, $\% 70, \% 80, \% 96$, $3 \times \% 100$ ) akciğer dokuları dehidrate edildi. Ksilol ile şeffaflandırıldıktan sonra parafine gömüldü. Parafin bloklardan alınan 5 um kalınlığındaki kesitlere histolojik yapıyı değerlendirmek amacıyla Masson trikrom boyaması yapıldı. Kaspaz-3 pozitif hücreler ise immunohistokimyasal yöntemle belirlendi.

\section{Masson-Trikrom}

Doku kesitleri $58^{\circ} \mathrm{C}$ ' de inkübe edildikten sonra ksilende 3 kez 10'ar dakika bekletildi. Dokuya su kazandırmak amaclyla azalan alkol $(2 x \% 100, \% 96, \% 80, \% 70$ ve $\% 50)$ serilerinden geçirilen kesitler çeşme suyuna getirilerek yıkandı. Hematoksilen ile çekirdekleri boyanan kesitler asit 
alkolden geçirildikten sonra 2 dakika asit fuksin solüsyonunda bekletildi. Kesitler distile su ile yıkandıktan sonra fosfomolibdik asit solüsyonunda 5 dakika bekletildi. Solüsyondan çıkarılan kesitler kurumaya bırakıldı. Anilin mavisi solüsyonunda 5 dakika bekledikten sonra asetik asitten geçirilen kesitler dereceli alkol serilerinden geçirilerek şeffaflandırılip kapatılı.

\section{İmmunohistokimya}

Dokudaki kaspaz-3 pozitif hücreleri belirlemek amacıyla immunohistokimya boyaması uygulandı. Avidin-Biotin-Peroksidaz yöntemi kullanıldı. Parafin bloklardan $5 \mu \mathrm{m}$ kalınlığında polilizinli lamlara alınan kesitler 1 gece $60{ }^{\circ} \mathrm{C}$ 'de etüvde bekletildikten sonra ksilen ve azalan dereceli alkol serilerinden $(\% 100, \% 96, \% 80, \% 70)$ geçirilerek rehidrate edildi. Kesitler daha sonra distile su ile 3 defa 5'er dakika yıkandı. Daha sonra antijen geri kazanımı için $\% 5^{\prime}$ lik sitrat tamponu ile mikrodalga firında 600W'de 5 dakika tutuldu. PBS ile tekrar yıkanan kesitler endojen peroksidaz aktivitesini engellemek için 12 dakika \%3 hidrojen peroksit $\left(\mathrm{H}_{2} \mathrm{O}_{2}\right)$ ile muamele edildi. Bundan sonraki aşamalar için Large Volume Detection System (Thermo Scientific, TP125-HL) immunohistokimya boyama kiti kullanıldı. Zemin boyasını engellemek için $5 \mathrm{dk}$. Ultra $\mathrm{V}$ blok ile muameleden sonra primer antikor (Kaspaz-3, Abcam, ab4051) ile +4 oC'de nemli ortamda bir gece inkübe edildi. Negatif kontrol için hazırlanan dokularda primer antikor yerine PBS kullanıldı, diğer basamaklardaki işlemler aynı şekilde yapıldı. Primer antikor uygulamasından sonra yıkama işlemi yapıldı. Biotinli-sekonder antikor, streptavidin HRP (Horse Radish Peroksidaz) ve DAB (3,3'-Diaminobenzidine) kromojeni uygulandıktan sonra Gill hematoksilenle zı t boyama yapıldı. Son olarak artan alkol serileri (\%70, \%80, \%96, $\% 100$ ) ile suyu uzaklaştııılarak ksilenden geçirilen kesitler kapatma solüsyonu (Entellan®,Merck) ile kapatılı. Olympus BX51 model ışık mikroskobu altında DP71 model dijital fotoğraf makinesi ile görüntüleri alındı (21). Kaspaz-3 hücre sayımı her gruptan 5 preparatta ve her preperattan da 5 ayrı çekilmiş fotoğraf üzerindeki immunreaktif tüm hücrelerin Image-J Programı kullanılarak sayılması ile yapıldı. Elde edilen veriler istatistiksel olarak değerlendirildi.

\section{Istatistiksel Analiz}

$\mathrm{Bu}$ çalışmada elde edilen verilerin değerlendirilmesinde SPSS 23.0 paket programı kullanıldı. Verilerin normal dağıııı Kolmogorov-Smirnov testi ile değerlendirildi. Veriler normal dağılım gösterdikleri için Anova testi ve Anova sonrasında gruplar arası anlamlı farkılıkları belirlemek için de Tukey HSD testi kullanıldı. İstatistiksel olarak $p<0,05$ değeri anlamlı kabul edildi.

\section{Bulgular \\ Histoloji, Masson-Trikrom Bulguları}

Kontrol grubu sıçanların akciğer dokularının histopatolojik incelemesi, doku bütünlüğünü bozmadan sağlıklı ve normal histolojiye sahip olduklarını gösterdi. Aynı şekilde L- karnitin verilen grupta da akciğer histolojisi benzer şekildeydi. Fakat CCl4 verilen grupta (Grup III) bronşiol epitelinde vakuolizasyon ve bozulma görüldü (Şekil 2). Alveoller arasında interstisyel doku yoğunluğunda bir artış vardı ve bu bölgelerde kısmen fibrozlu yapılar gözlendi. Grup IV ve $V$ ise Grup III'e benzer şekildeydi. Yalnız Grup IV de grup V'e göre daha fazla oranda interstisiyel doku artışı oluğu gözlendi (Şekil 2).

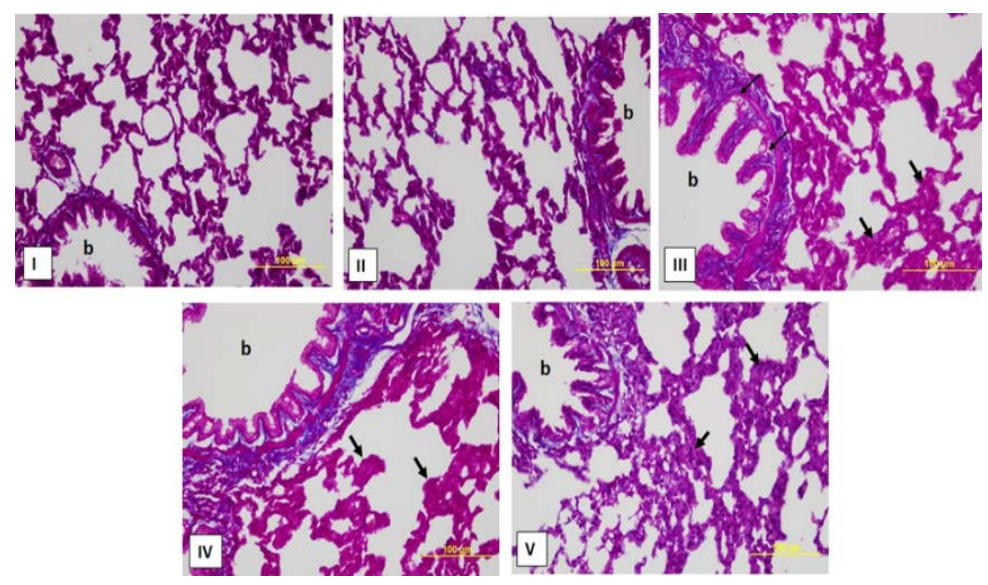

Şekil 2. Masson trikrom ile boyanan tüm gruplarda akciğer dokusunun histopatolojik görüntüleri.

Gruplar: (I) Kontrol grubu, (II) L- karnitin grubu, (III) CCl4 grubu, (IV) CCl4+ Lkarnitin grubu, (V) L-karnitin+CCl4. (kalın oklar: intersitisiyel alanlarda artış, ince oklar: bronşiol epitelinde vakuolizasyon ve dejenerasyon, b: bronşiol). Skala bar $=100 \mu \mathrm{m}$. (Masson Trikrom).

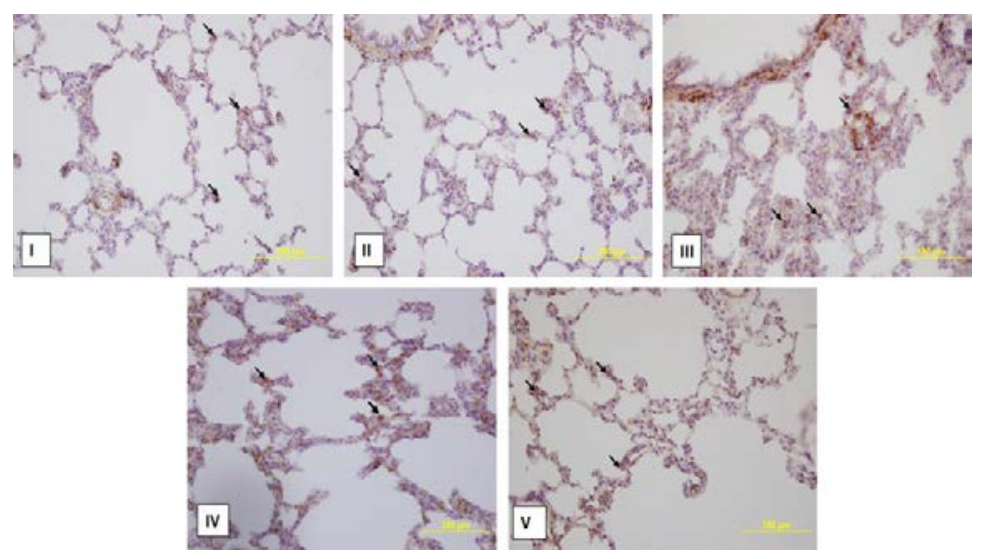

Şekil 3. Tüm gruplarda akciğer dokusunda Kaspaz-3 İmmunoreaktivitesi.

Gruplar: (I) Kontrol grubu, (II) L- karnitin grubu, (III) CCl4 grubu, (IV) CCl4+ Lkarnitin grubu, (V) L-karnitin+ CCl4. Kaspaz-3 immunoreaktif hücreler (oklar). Skala bar $=100 \mu \mathrm{m}$. (Immunohistokimya).

\section{İmmunohistokimya, Kaspaz-3 Aktivitesi Bulguları}

Bütün gruplardaki kaspaz-3 immunreaktivitesine sahip alveoler alanlar ışık mikroskobunda 40X'lık objektifte fotoğraflandı (Şekil 3). Imaje J programında tüm gruplarda kaspaz-3 immunoreaktif hücre sayımı yapıldıktan sonra istatistiksel olarak değerlendirildi. Veriler normal dağııım gösterdiği için parametrik analizler yapıldı. İstatistiksel analiz 
sonuçlarına göre Grup III ve V, kontrol grubuna göre anlamlı olarak yüksek bulunmuştur. L-karnitin CCl4'den önce verildiğinde kaspaz-3 hücre sayısı kontrol grubundan yüksekken, L-karnitin sonra verildiğinde kaspaz-3 hücre saylsının kontrol grubuna benzer şekilde olduğu görülmüştür (Tablo 1). L-karnitin'in sonra verilmesinin akciğer dokusunda kaspaz-3 aktivitesi açısından daha yararlı olduğunu söylemek mümkündür. Grup III'ün kaspaz-3 hücre sayısı ise kontrol grubuna göre anlamlı olarak yüksek bulunmuştur. Bu da CCl4'ün kaspaz-3 yoluyla akciğer dokusunda apoptozu artırdığı anlamına gelmektedir. Sadece L-karnitin verilen grubun ise kontrole benzer olduğu görülmüştür (Tablo 1).

Tablo 1. Kaspaz-3 hücre sayımı istatistik verileri.

\begin{tabular}{lll}
\hline Grup & $\mathbf{n}$ & $\mathbf{X} \pm \mathbf{S S}$ \\
\hline Grup I & 25 & $17,16 \pm 8,88$ \\
Grup II & 25 & $16,56 \pm 5,94$ \\
Grup III & 25 & $29,40 \pm 11,57^{\star}$ \\
Grup IV & 25 & $23,72 \pm 9,52$ \\
Grup V & 25 & $28,96 \pm 13,09^{\star}$ \\
\hline G
\end{tabular}

Grup I (kontrol grup), Grup II (L-karnitin); Grup III (CCL4); Grup IV (CCl4+ Lkarnitin); Grup V (L-karnitin+CCl4).

*Kontrol grubundan $p<, 05$ seviyesinde anlamlı olarak farkııdır.

One-Way ANOVA Post Hoc Tukey Testi

\section{Tartışma}

Karbon tetraklorür ( $\mathrm{CCl} 4$ ) kuru temizlemeden böceklerle mücadeleye kadar sıklıkla kullanılan oldukça toksik bir maddedir $(7,22,23)$. Bu kimyasalla temasın serbest radikallerin oluşumu ile oksidatif stresi indüklediği ve doku hasarına neden olduğu bilinmektedir (4). CCl4 gibi maddelerin oluşturduğu hasarlar nedeniyle hücrelerde apoptoz oluşabilir $(12,13)$. DNA'nın da oksidatif hasara karşı korunması apoptotik süreçlerin başlamasını engellemek için oldukça önemlidir. Hücre ölümü için gerekli hücre içi olaylardan biri de, kaspazların aktivasyonudur (12).

Yapılan bu çalışmada CCl4 kaynaklı kronik akciğer toksisitesi ve apoptoz mekanizmasında önemli bir rol oynayan kaspaz-3 enzim aktivitesinin hasarlı ve normal dokudaki değişimi immunohistokimyasal yöntemle araştıııldı. CCl4 ile indüklenen akciğer hasarının kaspaz-3 enzim aktivitesi üzerindeki etkisi ile ilgili sınırlı sayıda çalışmalar bulunmaktadır. Daha çok karaciğer üzerinde yapılan çalışmalar çoğunluktadır. $\mathrm{CCl} 4$ ile indüklenen karaciğer hasarında yapılan bir çalışmada nekrozu indüklediği ve bunun sonucunda oluşan oksidatif stresin kaspaz-3'ü aktive ederek ve apoptozu arttırdığı bildirilmiştir (24). Yine CCl4 ile yapılan çalışmalarda CCl4'ün kaspaz enzim sistemini aktive ederek apoptozu arttırdığı ve böylece doku hasarına yol açtığı bildirilmiştir $(8,25)$. Başka bir maddeyle karaciğer hasarının indüklendiği bir çalışmada kaspaz-3 pozitif hepatositlerin sayısı hasar oluşturulan grupta yüksek bulunmuştur (26). Akciğer dokusunda yapılan çalışmaları incelediğimizde ise, CCl4 ile oluşturulan akciğer hasarında kaspaz-3 enzim aktivitesi diğer gruplardan yüksek bulunmuştur (8). Akut CCl4 toksik dozu uygulanan bir çalışmada, $\mathrm{CCl}$ 'ün toksik etkisiyle alveoler makrofaj birikiminin artırabileceği ve TNFa ve NO üretimini uyarabileceği bildirilmiştir. Böylece, akciğerin kaspaz yolu aşırı aktive olup, doku hasarına yol açacağı ve bu aktivasyonun bazı maddelerle önlenebileceği belirtilmiştir (8).

CCl4 ile yapılan çalışmalarda ciddi akciğer doku hasarına neden olduğu ve bazı histopatoloijk değişikler oluştuğu belirlenmiştir. Deney hayvanları ile yapılan bu çalışmalarda akciğer doku örneklerinde; interstisyumda hemoraji, bronş ve bronşiol epitellerinde dökülme ve makrofaj infiltrasyonu gibi histopatolojik değişikliklere rastlanılmıştır $(10,27)$. Başka bir çalışmada akciğer dokusunda alveolar duvarların ve bronşiyollerin rüptürü, fibroblastların agregasyonu ve düzensiz Clara hücreleri gibi çeşitli histopatolojik bulgular gözlenmiştir. Terminal bronşiyolde iç epitel daralmış ve lümen azalmış ve sonuçta hava geçişi kısıtlanmıştır (1).

Miyamoto ve arkadaşlarının yaptığı çalışmada (28) CCl4 maruziyeti sonucu akciğerde fibrozise bağlı olarak ağırlık artışının ve pneumoninin meydana geldiğini bildirmiştir (7). Çalışmamızda CCl4 uygulanan grubun akciğer dokusu histolojisinde belirgin fark gözlenmiştir. Bu çalışmalara benzer şekilde alveolar intersitisiyel alanlarda artış, bronşiol epitelinde vakuolizasyon ve dejenerasyon gibi histopatolojik değişikliklere rastlanıldı.

LC'nin canlılarda birçok fizyolojik parametre üzerindeki olumlu etkisini açıklayan moleküler mekanizmalar henüz tam olarak anlaşılamamıştır, ancak literatürde bildirilen LC'nin birçok koruyucu etkisinin antioksidan etkisi ile ilişkili olduğu varsayılmıştır (29). Mitokondriyal disfonksiyon, apoptoz ve oksidatif stres birçok hastalığın patolojisine etki eden birbiriyle ilişkili olaylardır. L-karnitin glikoz ve yağ asitlerinin metabolizmasında kritik bir rol oynadığından, muhtemelen bu olumsuz olayları düzenleme potansiyeline sahiptir (30). Thangasamy ve arkadaşlarının yaptığı çalışmada yaşlanmış ratlara L-karnitin verilmesi hücredeki makro molekülleri (DNA, protein, lipid) okdidatif strese karşı korumaktadır (31). Bu nedenle, L-karnitin'in serbest radikalleri temizleyerek DNA hasarını önlemesi ve CCl4 ile oluşturulan akciğer hasarına karşı faydalı olması mümkün olabilir (18). Böbrek, karaciğer, testis ve midede kronik Lkarnitin takviyesi ile ilgili yapılan bir çalışmada, anti-apoptotik Bcl-2 ve pro-apoptotik Bax'ın protein ekspresyonunu düzenlediği, kaspaz-3 aktivitesini baskıladığı, toplam antioksidan kapasiteyi arttırdığı ve serbest radikalleri temizlediği bildirilmiştir. Elde edilen veriler, L-karnitin takviyesinin, periferik organlarda hem oksidatif hem de apoptotik ilerlemeyi azaltmak için potansiyel olarak kullanılabileceğini göstermektedir (20). L-karnitin, bu şekilde hücresel olaylara karşı koruyucu etkiler gösterdiğinden klinik ortamda, çeşitli ilişkili hastalıkları tedavi etmek için uygulanabilir (30). L-karnitin'in, CCl4'ün neden olduğu deneysel karaci- 
ğer hasarı ile ilgili yapılan bir çalışmada erken safhada koruyucu bir etkiye sahip olduğu, toksik etki veya hasar devam ettikçe etkisinin azaldığı bildirilmiştir (32).

Bu çalışmada da $\mathrm{CCl} 4$ grubunun akciğer dokularının histopatolojik değerlendirmesinde akciğer dokusu hasarı ve artan kaspaz-3 enzim aktiviteleri gözlemlendi. Diğer taraftan, CCl4 ile birlikte L-karnitin verilen gruplarda histopatolojik hasarlara rastlandı. Fakat L-karnitin'in CCl4'den sonra verildiği grupta daha düşük kaspaz-3 enzim aktivitesi vardı. L-karnitin'in $\mathrm{CCl} 4$ den önce verildiği grupta ise kaspaz-3 enzim aktivitesi kontrol grubuna göre anlamlı şekilde yüksekti. Bu sonuçlara göre $\mathrm{CCl} 4$ gibi ksenobiyotiklere maruz kalındığında kaspaz-3 enzim aktivitesini akciğer dokusunda düşürmek için L-karnitin tedavisinin etkili oluğunu söyleyebiliriz. Yani L-karnitin'in alveolear hasarda antiapoptotik ve histopatolojik olarak koruyucu etkisinden çok tedavi edici etkisinin daha yüksek olduğu görülmektedir. Sonuç olarak, alveolar hasar oluşumunda L-karnitin takviyesinin antiapoptotik etkisinin olduğu ve L-karnitin'in tedavi edici olarak kullanılmasının daha büyük önem taşıyacağını düşünmekteyiz.

\section{Açıklamalar}

Etik onam: Bu çalışma Erciyes Üniversitesi Bilimsel Araştırma Projeleri Birimi tarafindan TSA-2018-8227 kodlu proje ile desteklenmiştir. Bu projede kullanılan dokular için Erciyes Üniversitesi Hayvan Deneyleri Yerel Etik Kurulu tarafindan (14.02.2018 tarihli onay, 18/034 sayılı karar) etik kurul onay belgesi alınmıştır.

\section{Kaynaklar}

1. Naz K, Khan MR, Shah NA, Sattar S, Noureen F, Awan ML. Pistacia chinensis: A potent ameliorator of $\mathrm{CCl} 4$ induced lung and thyroid toxicity in rat model. BioMed Res Int. 2014;2014:192906.

2. Rahmouni F, Badraoui R, Amri N, Elleuch A, El-Feki A, Rebai T, et al. Hepatotoxicity and nephrotoxicity in rats induced by carbon tetrachloride and the protective effects of Teucrium polium and vitamin $C$ Toxicol Mech Methods. 2019;29(5):313-21.

3. Manjrekar AP, Jisha V, Bag P, Adhikary B, Pai M, Hegde A, et al. Effect of Phyllanthus niruri Linn. treatment on liver, kidney and testes in CCl4 induced hepatotoxic rats. Indian J Exp Biol. 2008;46(7):514-20.

4. Ganie SA, Haq E, Hamid A, Qurishi Y, Mahmood Z, Zargar BA, et al. Carbon tetrachloride induced kidney and lung tissue damages and antioxidant activities of the aqueous rhizome extract of Podophyllum hexandrum. BMC Compl Alternative Med. 2011;11(1):17.

5. Khan RA. Protective effect of Launaea procumbens (L.) on lungs against $\mathrm{CCl} 4$-induced pulmonary damages in rat. BMC Compl and Alternative Med. 2012;12(1):133.

6. Ahmad B, Khan MR, Shah NA. Amelioration of carbon tetrachlorideinduced pulmonary toxicity with Oxalis corniculata. Toxicol and Ind Health. 2015;31(12):1243-51.

7. Gülcen B, Kuş MA, Çolakoğlu S, Ögetürk M, IIlter K, Ersoy MA, et al. Deneysel karbon tetraklorür zehirlenmesinde akciğer doku hasarı ve melatonin hormonunun koruyucu rolü: Işık mikroskobik ve biyokimyasal bir çalışma. Düzce Tıp Fakültesi Dergisi. 2012;14(3):37-42.

8. Kurt A, Tumkaya L, Yuce S, Turut H, Cure MC, Sehitoglu I, et al. The protective effect of infliximab against carbon tetrachloride-induced acute lung injury. Iran J Basic Med Sci. 2016;19(6):685.

9. Ganie SA, Haq E, Masood A, Zargar MA. Amelioration of carbon tet- rachloride induced oxidative stress in kidney and lung tissues by ethanolic rhizome extract of Podophyllum hexandrum in Wistar rats. J Med Plant Res. 2010;4(16):1673-7.

10. Firat T, Ulas N, Terzi EH, Töre F, Kükner A. The Effect of Experimental Liver Injury on Lung and Role of Mast Cells. Turkiye Klinikleri J Med Sci. 2013;33(4):1182.

11. Mizuguchi S, Takemura S, Minamiyama Y, Kodai S, Tsukioka T, Inoue $\mathrm{K}$, et al. S-allyl cysteine attenuated CCl4-induced oxidative stress and pulmonary fibrosis in rats. Biofactors. 2006;26(1):81-92.

12. Yalcin A, Yumrutas O, Kuloglu T, Elibol E, Parlar A, Yilmaz I, et al. Hepatoprotective properties for Salvia cryptantha extract on carbon tetrachloride-induced liver injury. Cell Mol Biol. 2017;63(12):56-62.

13. Obermayer-Straub P, Manns MP. Immunological mechanisms in liver injury. Drug-induced liver disease. 2002:125.

14. Kerr JF, Winterford CM, Harmon BV. Apoptosis. Its significance in cancer and cancer therapy. Cancer. 1994;73(8):2013-26.

15. Kawasaki M, Kuwano K, Hagimoto N, Matsuba T, Kunitake R, Tanaka T, et al. Protection from lethal apoptosis in lipopolysaccharideinduced acute lung injury in mice by a caspase inhibitor. Am J Pathol. 2000;157(2):597-603.

16. Xie J, Liu J, Chen TM, Lan Q, Zhang QY, Liu B, et al. Dihydromyricetin alleviates carbon tetrachloride-induced acute liver injury via JNKdependent mechanism in mice. World $\mathrm{J}$ Gastroenterol. 2015;21(18):5473-81.

17. Kaya O, Koca YS, Barut I, Baspinar S, Sabuncuoglu MZ. L-carnitine reduces acute lung injury in experimental biliary obstruction. Saudi Med J. 2015;36(9):1046-52.

18. Tousson E, Hafez E, Zaki S, Gad A. P53, Bcl-2 and CD68 expression in response to amethopterin-induced lung injury and ameliorating role of L-carnitine. Biomed Pharmacother. 2014;68(5):631-9.

19. Sener G, Paskaloglu K, Satiroglu H, Alican I, Kaçmaz A, Sakarcan A. L-carnitine ameliorates oxidative damage due to chronic renal failure in rats. J Cardiovasc Pharmacol. 2004;43(5):698-705.

20. Kelek SE, Afsar E, Akcay G, Danisman B, Aslan M. Effect of chronic $\mathrm{L}$-carnitine supplementation on carnitine levels, oxidative stress and apoptotic markers in peripheral organs of adult Wistar rats. Food Chem Toxicol. 2019;134:110851.

21. Yildirim AB, Ozdamar S, Yalcin B, Karabulut D. Changes in MAP-2 and GFAP immunoreactivity in pup hippocampus during prepubertal and pubertal periods caused by maternal subclinical hypothyroidism. Eur J Anat. 2019:27-40.

22. Weber LW, Boll M, Stampfl A. Hepatotoxicity and mechanism of action of haloalkanes: carbon tetrachloride as a toxicological model. Crit Rev Toxicol. 2003;33(2):105-36.

23. Thrall KD, Vucelick ME, Gies RA, Benson J. Comparative metabolism of carbon tetrachloride in rats, mice, and hamsters using gas uptake and PBPK modeling. J Toxicol Env Heal A. 2000;60(8):531-48.

24. Kukner A, Tore F, Firat T, Terzi EH, Oner H, Balaban YH, et al. The preventive effect of low molecular weight heparin on CCL4-induced necrosis and apoptosis in rat liver. Ann Hepatol. 2010;9(4):445-54.

25. Bahashwan S, Hassan MH, Aly H, Ghobara MM, El-Beshbishy HA, Busati I. Crocin mitigates carbon tetrachloride-induced liver toxicity in rats. J Taibah Univ Sci. 2015;10(2):140-9.

26. Sayan M, Karabulut D, Özdamar S. Assessment of the protective and therapeutic effect of melatonin against thioacetamide-induced acute liver damage. J Biochem Mol Toxic. 2020:e22450.

27. Ögetürk M, Çolakoğlu N, Kuş MA, Kuş İ, Sarsilmaz M. Karbon tetraklorür ile oluşturulan deneysel akciğer hasarında kafeik asit fenetil esterin koruyucu etkinliği. FÜ Sağ Bil Tıp Derg. 2009;23(2):57-61.

28. Miyamoto K. Experimental study on changes of the pulmonary vessels in the cirrhotic rats. Nihon Geka Gakkai zasshi. 1995;96(1):44-53. 29. Surai PF. Antioxidant action of carnitine: molecular mechanisms and practical applications. EC Veterinary Science. 2015;2(1):66-84.

30. Modanloo M, Shokrzadeh M. Analyzing Mitochondrial Dysfunction, Oxidative Stress, and Apoptosis: Potential Role of L-carnitine. Iran J Kidney Dis. 2019;13(2):74. 
31. Thangasamy $T$, Jeyakumar $P$, Sittadjody S, Joyee AG, Chinnakannu P. L-carnitine mediates protection against DNA damage in lymphocytes of aged rats. Biogerontology. 2009;10(2):163-72.

32. Demirdag K, Bahcecioglu IH, Ozercan IH, Ozden M, Yilmaz S, Kalkan $A$. Role of $L$-carnitine in the prevention of acute liver damage induced by carbon tetrachloride in rats. J Gastroenterol Hepatol. 2004;19(3):333-8. 